\title{
Resistance of the Defeated: German and Italian Big Business and the American Antitrust Policy, 1945-1957
}

\author{
LUCIANO SEGRETO \\ BEN WUBS
}

The article addresses the question to what extent American antitrust policy in Germany and Italy during the 1950s, was a success or not. Did these nations adopt this policy, did they adapt themselves to it, or did they completely reject it? By a detailed comparison of these two big European nations, Germany and Italy_-both defeated powers of the Second World War, and both therefore strongly dependent on postwar American aid-the effects of the American antitrust policy will be analyzed. Eventually, the Germans better adapted, after initial resistance of German big business, to the American plans than the Italians, however, only in an amended and softer form. The Italian resistance-but we even use the expression prolonged rejection— to the economic reforms were much stronger. The US administration envisioned a unified free European market without cartels as early as 1943, however, it would take another fifty years before these ideas would be implemented.

In seeking to establish a free market economy in Europe, the United States is attempting therefore to bring about a fundamental change in thinking and institutions approaching the dimensions of a social revolution. Furthermore, since we are democrats we are seeking to bring about a peaceful revolution and one that is not imposed from

() The Author 2014. Published by Oxford University Press on behalf of the Business History Conference. All rights reserved. For permissions, please e-mail: journals.permissions@oup.com

doi:10.1093/es/khu001

Luciano SEgReto is the Professor at School of Political Sciences, University of Florence, Polo del Scienze Sociali, 50127 Florence, Italy. Contact information: School of Political Sciences, University of Florence, Polo del Scienze Sociali, 50127 Florence, Italy. E-mail: segreto@unifi.it.

BEN Wubs is an Associate Professor at Erasmus School of History, Culture and Communication, Erasmus University Rotterdam. Contact information: Erasmus School of History, Culture and Communication, Erasmus University Rotterdam, Box 1738, 3000DR Rotterdam, the Netherlands. E-mail: wubs@eshcc.eur.nl. 
the top, but is an expression of the desires of the community as a whole. ${ }^{1}$

ECA, Office of Special Representative in Europe, Paris, 1951

The standard narrative about the introduction of antitrust legislation in Europe is that it must largely be attributed to the influence of the United States. ${ }^{2}$ Before the war European governments had hardly enacted laws in this area. Antitrust literature underlines the effort made by the American government in post-World War II period in the Old Continent to push Western European countries to introduce this legislation and to reduce the level of concentration of the European economies. This article will investigate and compare these attempts in the two defeated countries, Germany and Italy, where economic and political conditions seemed to appear to the US administration most favorable to their initiative.

After the Allied occupation of Germany in 1945 the United States, as the strongest power of the three Western occupation forces, imposed their antitrust policy on the other two less enthusiastic powers, Great Britain and France. Of the three Western allied forces the Americans had the harshest policy in their treatment of Germany's monopolistic and highly cartelized industry. ${ }^{3}$ In 1948, the US government used Marshall Aid to impose its views on antitrust policy in West Germany and in the rest of aid-receiving Europe. In Italy, the country that shared with the Nazi regime the responsibility for World War II, the US administration nonetheless had apparently a softer approach, considering that in this country cartels were relatively less important, at least in their international impact, although they were strong and numerous at the national level. Paradoxically in the end, despite the quite relevant difference between the economic size of the two countries and the force of the business communities, the Americans faced a stronger resistance against any attempt to eliminate or to reduce restrictive business practices in Italy, partly because of the importance of the

1. US National Archives and Records Administration (NARA), RG.469, Office of Special Representatives in Europe, Office of the general counsel (OGC), Folder restrictive business practices, 1950-1953, Apr 1951.

2. Wyatt Wells, Antitrust \& the Formation of the Postwar World (New York: Columbia University Press, 2002), passim. Tony A. Freyer, Antitrust and Global Capitalism, 1930-2004 (New York: Cambridge University Press, 2006), 396-97. The argument of Freyer, however, is much more subtle than Wells'. According to Freyer US commanders in Germany delegated the introduction of an antitrust policy to a group of anti-Nazi leaders, in particular the Ordo Liberals. Furthermore, he points to the fact that US antitrust policies had unintended outcomes in Western Europe.

3. S. Jonathan Wiesen, West German Industry and the Challenge of the Nazi Past, 1945-1955 (Chapel Hill: The University of North Carolina Press, 2001), 42-44. 
state-owned companies, partly because of the oligopolistic structure of Italian industrial capitalism, but also because of the different tradition of the juridical thought compared to Germany. ${ }^{4}$

After the Second World War American foreign economic policy was based on two big pillars: international trade liberalization and a new monetary system. Both were the instruments for a new US hegemony, but also for a new stability of the international system after more than two decades of instability as a result of the very precarious balance of power among the big countries after the First World War. But these elements were also part of a more general framework. The transformation of the US economy after the big crisis of 1929 included the introduction of a series of regulatory instruments (the Glass-Steagall Banking Act, the Public Utilities Company Holding Act, Regulation $\mathrm{Q}$, the extension of the powers given to the Federal Trade Commission, etc.), that were the adaptation to new times and circumstances of the American antitrust culture. As a result, it cannot be considered a surprise that antitrust policy became one of the most important instruments of America's policy to build a new liberal economic world order. ${ }^{5}$

Several scholars have extensively analyzed the different forms of Americanization that took place among the European firms, managers, and business elites through the transfer of technologies, organizational capabilities, managerial skills, and mass consumption policies. From the first studies by Charles Maier on the productivity drive to the long list of contributions dealing with national and/or firm case studies it has been underlined, with a few exceptions, that the US proposals met different reactions, going from the enthusiastic (if not uncritical) acceptance of the new business credo to more critical (if not skeptical) responses. Nevertheless, a dominant interpretation has suggested the need to separate the immediate from the long-term effects of the US initiative, and has also specified that even in the case of a successful transfer of the US business and managerial culture to

4. Giorgio Mori, "L’economia italiana tra la fine della seconda Guerra mondiale e il "secondo miracolo economic," (1945-58)," in Storia dell'Italia repubblicana, volume primo, la costruzione della democrazia. Dalla caduta del fascismo agli anni cinquanta (Turin: Einaudi, 1994), 169-73; Nicola Rossi and Gianni Toniolo, "Italy," in Nicholas Crafts and Gianni Toniolo eds., Economic Growth in Europe since 1945 (Cambridge: CUP, 1996), 439-41; Luciano Segreto, "The Importance of the Foreign Constraint: Debates about a new Social and Economic Order in Italy, 1945-1955," in Dominik Geppert ed., The Postwar Challenge. Cultural, Social, and Political Change in Western Europe, 1945-58 (Oxford: OUP, 2003), 129-35.

5. Diana B. Kunz, Butter and Guns. America's Cold War Economic Diplomacy (New York: Free Press, 1997). 
Europe (and Japan) the phenomenon was more an adaptation than an adoption process. ${ }^{6}$

Part of literature, however, suggests that one the effects of the Americanization policy has been a successful, although not immediate, adoption of antitrust legislation. For example, Marie-Laure Djelic underlined the coherent longstanding roadmap starting with the discussion on the Schumann plan, to the Treaty of the European Steel and Coal Community in 1951, particularly article 65 and 66 (and not 60 and 61 as she states three times), eventually leading to the Treaty of Rome in 1957, with articles 85 and 86 about European antitrust policy. ${ }^{7}$ This permits her to conclude that antitrust legislation had "direct and unmistakable American origins."

This article addresses the question to what extent American antitrust policy in Europe, particularly in Germany and Italy during the 1950s, was a success or not. Did they adopt this policy, did they adapt themselves to it, or did they completely reject it? Even when the American views on cartels and other restrictive business practices were eventually leading to the Treaty of Rome in 1957, their concrete implementation could be more a (superficial) adaptation than a serious and scrupulous adoption. By a detailed comparison of two

6. Charles Maier, "Politics of Productivity: Foundations of American Economic Politics after World War II," International Organisation 31 (1977): 707-33; Jacqueline McClade, "Lo zio Sam ingegnere industriale. Il programma Americano per la produttività e la ripresa economica dell'Europa occidentale 1948-1958," Studi storici 36 (1996): 9-40. Marie-Laure Djelic, Exporting the American Model. The Post-war Transformation of European Business (New York: OUP, 1998); Matthias Kipping and Ove Bjarnar, eds., The Americanisation of European business: the Marshall Plan and the transfer of US management models(London: Routledge, 1998); Jonathan Zeitlin and Gary Herrigel, eds., Americanization and its limits. Reworking US technology and management in post-war Europe and Japan (Oxford: OUP, 2000); Dominique Barjot, ed., Catching-up with America: Productivity Missions and the Diffusion of American economic and technological influence after the Second World War (Paris: Press de Université de Paris Sorbonne, 2002); Matthias Kipping and Nick Tiratsoo, eds., Americanisation in the Twentieth Century Europe: Business, Culture, Politics, vol. 2 (Lille, Centre d'Histoire de l'Europe du Nord-Ouest Université Charles-de-Gaulle Lille 3, 2002); Harm Schröter, Americanisation of the European Economy. A compact survey of American economic influence in Europe since the 1880s (Dordrecht: Springer, 2005).

7. Marie-Laure Djelic, "Does Europe mean Americanization? The Case of Competition” Competition \& Change, 6 (2002): 245; "Declaration Robert Schuman, May 9, 1950." Accessed Jan 23, 2013. http://europa.eu/about-eu/basic-information/ symbols/europe-day/schuman-declaration/index_en.htm; "Treaty of European Coal and Steel Community, 1951.” Accessed January 23, 2013. http://www. proyectos.cchs.csic.es/euroconstitution/library/historic\%20documents/Paris/ TRAITES_1951_CECA.pdf; “Treaty of Rome, 1957.” Accessed January 23, 2013. http://ec.europa.eu/economy_finance/emu_history/documents/treaties/rometreaty2.pdf.

8. Djelic, "Does Europe mean Americanization," 246. 
big European nations, Germany and Italy-both losing powers of the Second World War, and both therefore strongly dependent on postwar American aid - the effects of this policy up to the Treaty of Rome will be assessed. Similarities as well as differences between the two cases will be analyzed and evaluated. The article closely looks into US government documents regarding the implementation of antitrust policy in occupied Germany, the Federal Republic of Germany, and Italy. In addition, it will explore West German and Italian government papers, as well as the position taken by interest groups of German and Italian big business. By comparing formal and informal relations between the German and Italian governments and national and international firms operating in both countries on the one hand, and the American government on the other, the article discusses both changes and continuities within national and transnational economic institutions in the immediate postwar period.

\section{The US Perception of European Restrictive Business Practices}

US antitrust legislation experienced several seasons. Cartels and other monopolistic practices had been under attack in the United States since the turn of the nineteenth century. The Sherman Act in 1890 had forbidden monopolistic practices; however, the Webb Act of 1918 had granted some indemnity from antitrust law to American firms who were allowed to join associations active in the export trade. ${ }^{9}$ Before the Second World War, US government action against domestic business combines, trust and monopolies and their international operations, however, had not always been consistent. The downturn of the economy during the Great Depression resulted in a relaxation of antitrust governance in the United States. In the first part of the New Deal Roosevelt regarded ruinous competition as one of main causes of the depression itself. The National Industry Recovery Act (NIRA) put antitrust policy on hold for some years. However, the end of NIRA in 1935 was followed by policies to decrease the levels of concentration in the American economy, which tried to counterbalance the unintended effects of the NIRA policy. The extension of the Federal Trade Commission's powers in March 1938 permitted this institution to supervise the firms "deceptive or unfair practices." 10

9. Unilever Archives Rotterdam (UAR), DIR 21, 346.2, McClellan, G.S.,"Role of Cartels in Modern Economy” Foreign Policy Reports, October 15, 1944 (New York).

10. Gérard Dumenile, Mark Glick, Dominique Levy, "History of Competition Policy as Economic History” in Antitrust Bulletin, vol. 42 (1997), pp. 373-417. Alan Jay Schottenstein, An analysis of the Wheeler-Lea Act and its Administrative Agency, The Federal Trade Commission, MBA Thesis (The Ohio State University 1951). 
Following Roosevelt's famous message to the Congress on April 29, 1938 on "Curbing Monopolies" the Temporary National Economic Committee was set up in June 1938 to investigate the level of growing concentration of economic power in the United States. ${ }^{11}$ The final report was published in March 1941 accompanied by eighty volumes of proceedings of the committee and several reports and monographs on different economic sectors. The progressive change of climate against big business and their cartels of the US administration is confirmed by the fact that in the 1938-1942 period 312 suits had been filed against American firms involved in international arrangements having violated antitrust laws, while in the 1933-1937 period only 30 cases had been filed. ${ }^{12}$

During the same period the terminology about the target of the campaign evolved continuously, giving the impression that its use was consistent with the role of several pressure groups (big corporations, different sectors of the political elites, laws experts, academics, etc.), the sensitiveness they could develop, and the necessity for the US administration to avoid any tension with the business community during the recovery from the depression and even more during the war's effort. If in the political and administrative jargon the expression "antitrust" had a specific meaning and/or an interpretation, which actually changed according to time from the beginning of the discussion about the Sherman Act and its implementation, the decision to use in some case "anticartel" or in other cases the even wider (and to some extent also less precise) concept of "restrictive business practices," when dealing with this issue abroad, clearly meant that there was a domestic and a foreign interpretation of the concept and its rhetoric. Strategic reasons as well as the desire to keep good relations with the US business community can explain this controversial attitude of the US administration. In this article we will be using mainly the last two expressions, according to the documents and the political and juridical culture of the 1940s and 1950s, while the shift in some cases to "antitrust" will only have an instrumental meaning as a synonymous of the same campaign.

US administration started to consider the anticartel policy towards Europe long before launching the military campaign to free the Continent from the Axis troops, when America was still warming up the industrial and military machinery that would lead to victory in 1945. In fact, in 1942 an interdepartmental committee, headed by the

11. Franklin D. Roosevelt: "Message to Congress on Curbing Monopolies.," Apr 29, 1938. Online by Gerhard Peters and John T. Woolley, The American Presidency Project.

12. Neil Fligstein, The transformation of corporate control (Cambridge, MA: Harvard University Press 1990), 168. 
joint-secretary for economic affairs Dean Acheson, was set up, at the Secretary of State's suggestion, to study all elements and factors that could negatively intervene against the economic development and international free trade. The final results were approved by Roosevelt, and later written down in article 7 of the Land-Lease Agreement. The text suggested that-in return for US aid and assistance-any "recipients agreed to eliminate both private and public barriers to trade." ${ }^{13}$

It appeared nonetheless evident to the more pragmatic sectors of the administration that that article was extremely clear but also very generic. It was necessary to go further, to find a solid, but also elastic instrument that could be used both to implement that policy, and to find the compromise to permit a reasonable success of the campaign. So in January 1943 a confidential document of the State Department affirmed that:

the future of the cartel and other forms of business combination in the post-war economic organization of Europe present numerous problems of possible interest to this government, particularly in view of its traditional anti-trust policy and its interest in the future management of German industrial holdings. ${ }^{14}$

Not so different words were used the same year in a very famous booklet written by Joseph Borkin (chief of the Patent and Cartel section of the Antitrust Division of the Department of Justice), and Charles A. Welsh about cartels in Germany and their negative role for the international post war economy. ${ }^{15}$ Furthermore, the State Department's analysis showed that cartels were present everywhere in Europe, although France, Germany, and United Kingdom dominated the situation at least for the international cartels with, respectively, 67, 57, and 53 international agreements in which firms of those countries were involved. Switzerland came forth in this ranking with 25 agreements, followed by Netherlands and Belgium with 20; then came Czechoslovakia (17), Sweden and Norway (16), and finally Italy with only 15 agreements, at the same ranking as Austria. But even more dramatic was the level of production and exports that were controlled through these agreements especially in some of the most

13. NARA, RG 59, Lot files, Economic bureau, international business practices division, 1944-1952, Folder restrictive business practices, 1944-1949, Mr. Jackson memorandum on restrictive business practices, Oct 17, 1949.

14. NARA, RG 59, Lot files, Economic bureau, international business practices division, 1944-1952, Folder restrictive business practices, 1944-1949, "Cartels and other forms of private monopoly in European economic reconstruction," Jan 15, 1943, 1.

15. J. Borkin and C. A Welsh, Germany's master plan. The story of industrial offensive (New York: Duell, Sloan and Pearce, 1943). 
important commodities (cobalt, copper, tin, tungsten, mercury, aluminum, lumber, rubber, white lead, etc.). In Europe in many cases it amounted to 100 percent of the total production and a very close percentage of total exports. On a global scale between two-thirds and 100 percent of the production was controlled by cartel agreements, depending on the commodity. ${ }^{16}$

The same document is extremely important because it was linking anticartel and antimonopolistic policy for postwar Europe with the assumption that the Old Continent was supposed to move towards a process of "unification," that would have certainly induced the growth of cartels. As a result, the possibility to eliminate or to limit the influence of these combines depended on "the scope of the powers granted to an international administrative authority," and on "the type of economic system which [was supposed] to be established" at the end of the war. ${ }^{17}$

The visionary analysis formulated in this document highlighted a story that has largely been the effective trajectory of European Economic Community (EEC) and then of European Union (EU) in the last decades:

it would be possible to have an European authority whose power in the economic field which were superior in certain matters of international concern to those of individual nations, but which were exercised only to secure the general framework of European economic life. In this case the authority might establish uniform customs duties, labour standards, monetary and credit facilities, and commercial laws. Subject to the conditions thereby created, individual firms would operate in a free market. ${ }^{18}$

It seemed quite clear to the Americans that Europe would only solve the collusive features of its economy and create free competition by means of a general economic planning. However, at the end the document was quite pessimistic about the possibilities of introducing a completely free market, because of the force and resistance of cartels, and the low degree of compromises that the balance of institutional and economic powers could permit. In fact, even the less optimistic proposal to fight the cartels was not too far from the outcome of the historical process during the 1950's. In the future "European economic authority" might also propose the establishment of a mixed economy permitting cartels and other forms of combination to exist, but under "public control." The paradox of this policy, if followed till the extreme consequences, was to require the "compulsory

16. "Cartels and other forms of private monopoly," 5 and 10.

17. Ibid; 17.

18. Ibid; 18. 
cartelization" or corporate consolidation of firms in certain industries. The example offered was not too far away from what would become the European Community of Coal and Steel from its birth, an institution charged of various activities:

the fixing of prices and production quotas (...) the designation of market territories or the establishment of a central selling board. Its regulatory mandate could also be extended to new capital investments, technical methods, allowable profit returns, the opening of new sources and the closing down of old, with the attendant problems of compensating owners thus forced out of production. ${ }^{19}$

So, from this very initial process of analyzing the complexity of cartels and other forms of combinations among firms in Europe it appeared clear-at least to a part of the US administration-that the battle of principles could be won not only by insisting on the correctness and superiority of the American antimonopolistic and antitrust policies, but, simultaneously introducing some new institutions at the European level that could control, fight-but also interact withany form of restrictive business practices.

The best and most visible result of the work done between 1942 and 1945 was a sort of progressively superior level of analysis and intervention, that slowly reduced-if not eliminated-the use of the word "cartel" with the more complex but also less comprehensible expression of "restrictive business practices," in a sort of ante litteram politically correctness. The new terminology most probably might have also been introduced to please US Big Business. ${ }^{20}$ In the meanwhile, domestic "trust busting" had come to a complete standstill. ${ }^{21}$ The new aims of the US campaign, summed up by the secretary of State Department Cordell Hull in a letter to president Roosevelt, were based on the assumption that:

the elimination of restrictive business practices of cartels is an objective that consistently follows from liberal principles of international trade which this government, under your direction, has constantly sought to implement through the trade agreements program and other aspects of commercial policy. It is also an objective which consistently follows from this country's traditional

19. Ibid; 21.

20. Paul A.C. Koistinen, Arsenal of World War II: the political economy of American warfare, 1940-1945 (Lawrence: University Press of Kansas, 2004), 466.

21. Wells, Antitrust, 96-97. Robert Franklin Maddox, The War Within World War II. The United States and International Cartels (Westport, CT: Praeger, 2001), 32. 
and long-standing program design to protect the consumer against monopoly and to preserve individual enterprise on a freely competitive basis. ${ }^{22}$

The concrete implementation of these ideas and principles was, however, more difficult, and its final results were less successful than those expected or, better, officially proclaimed. Especially, when this campaign was launched in Europe, passing from just an intellectual debate to a concrete discussion with political and economic partners, it became immediately evident, as in many other policies launched by the US administration in those years and during the Marshall Plan, that reality was much more complex, and less willing to be changed according to the US desires.

\section{Role of Cartels and Monopolistic Practices in Germany}

Prewar Germany was by large the most highly cartelized economy in the world. According to the assistant Attorney General of the United States in 1944, Germany was even the "classic land of the cartel." ${ }^{23}$ At the beginning of the First World War there existed around 700 cartels in the country. ${ }^{24}$ After the war, when Germany had lost all its foreign property it searched for an alternative internationalization strategy, and consequently became closely involved in numerous international cartels. However, also inside Germany the number of cartels increased; estimates vary from 1,500 to 2,500 horizontal market agreements during the 1920s. A few months after Hitler's takeover the regime issued a decree of compulsory cartels. As a result, during the 1930s there existed more than 3,000 cartel agreements in Germany. ${ }^{25}$ Cartelization, however, did not prevent concentration in the German industry. In particular, during the 1920s large industrial trusts were set up after mergers in the chemical and steel industry. The result had been the formation of the largest chemical company in the world, IG Farben, and steel giant Vereinigte Stahlwerke. However, also in the German electromechanical sector Siemens \&

22. NARA, RG 59, Lot files, Economic bureau, international business practices division, 1944-1952, Folder restrictive business practices, 1944-1949, Cordell Hull to the President, Sep 11, 1944.

23. Wendell Berge, Cartels, Challenge to a Free World (Washington: Public Affairs Press 1944), 5.

24. Volker R. Berghahn, The Americanisation of West German Industry (Leamington Spa: Berg 1986), 20-21.

25. Berghahn, The Americanisation, 20-23. Geoffrey Jones, Multinationals and Global Capitalism from the Nineteenth to the Twenty-first Century (Oxford: Oxford University Press, 2005), 31. 
Halske, AEG and Robert Bosch AG had developed into highly integrated giant companies. ${ }^{26}$

Clause 12 of the Potsdam Agreement of July 1945 provided that German industry should be decentralized for the purpose of eliminating excessive concentrations of economic power. ${ }^{27}$ Soon after Potsdam the Big Four sanctioned Law No. 9 which provided for the seizure and control of Germany's largest trust IG Farben, whose directors would also be tried in Nuremberg as Nazi criminals. The difference between the Big Four as regards the treatment of German industry nonetheless soon appeared. The British in their zone promoted a constructive approach to German industry, according to the ideals of the ruling Labour Party. The French had a similar attitude, they wanted to contain German industry, not destroy it. Soviet anticapitalist policy towards German industry came down to the nationalization and dismantling of German companies. ${ }^{28}$

Of the three Western occupying powers the Americans had the most severe policy regarding the treatment of German industry. ${ }^{29}$ They were determined to hold the leaders of German industry responsible for their collaboration with the Nazis. Henry Morgenthau's radical proposal of 1944 to dismantle Germany's heavy industry of the Ruhr was nonetheless replaced in 1945 by a Joint Chiefs of Staff policy directive (JCS 1067). It explicitly outlawed cartels and called up for the break-up of large business conglomerates. In January 1947, the Americans and British merged their zones of occupation and in July the Americans abandoned JCS 1067. From then on the British and Americans coordinated their policy and established the Bipartite Decartelization Commission (BIDEC). They had adopted two laws, Law 56 for the American zone and Law 78 for the British zone. These laws were practically identical in their terms. Article 1 provided for the prohibition and elimination of restrictive and monopolistic enterprises, practices, and excessive concentrations of German economic power. Cartels, combines, and various other concerted undertakings, having the purpose or effect of restraining domestic or international trade or fostering monopolistic control or restricting access to markets, were declared to be excessive concentrations.

Companies having their headquarters in the American or British zone and employing more than 10,000 people were to be examined prima facie as excessive concentrations and were to be

26. Hans-Joachim Braun, The German Economy in the Twentieth Century. The German Reich and the Federal Republic (London: Routledge, 2011), 50.

27. UAR, DIR 23, 348.1, Report of the Committee appointed to review the Decartelisation Program in Germany, Apr 15, 1949, 15.

28. Wiesen, West German Industry, 42-43.

29. Ibid. 
deconcentrated ${ }^{30}$ On the basis of a comprehensive study it was concluded that there existed 69 separate industrial combines which were appropriate for further investigation and further action. Obviously, given this large number of companies, not all actions could be taken at once. Therefore it was decided in June 1947 to select six companies to start with, that is, Henschel \& Sohn, Robert Bosch GmbH, Siemens \& Halske, Metallgesellschaft AG, Vereinigte Kugellager Fabriken (VKF), and Gutehoffnungshuette AG. After a period of six months, four other principal combines would be chosen, and so on. ${ }^{31}$

Deconcentration activities by the Military Government in Germany related to IG Farben, the steel and iron companies in the Ruhr, and the German banking system were handled outside the Decartelization Branch. In 1945, IG Farben property had been sequestrated by the Military Government and its huge conglomerate dismantled into independent operating units, although its definitive legal break-up would be delayed until the early 1950s. ${ }^{32}$ Deconcentration of the largest German banks, the Deutsche Bank, the Dresdner Bank, and the Commerz Bank, had been vigorously prosecuted to eliminate their concentration of economic power. Before the German currency reform in 1948 the German banking system was reorganized and the principal banks were all administered by an independent (state) custodian. ${ }^{33}$ The coal, iron, and steel combines were located mainly in the Ruhr, which was part of the British zone. At first the British operated these industries as part of large business conglomerates. Later on the British, in contrast to their overall policy in their zone, started to deconcentrate extensively through the creation of twenty-five to thirty separate units. ${ }^{34}$ US military governor Lucius Clay expressed his disapproval of the British "self-seeking” policy concerning German heavy industry, and he feared that they were "protecting their own enterprises in their own country." 35

In 1948, however, dissatisfaction arose inside the US Decartelisation Branch about General Clay's statement that Henschel \& Sohn was not a proper subject for a deconcentration action. ${ }^{36} \mathrm{He}$ did not believe

30. UAR, DIR 23, 348.1, Report of the Committee appointed to review the Decartelisation Program in Germany, 33-34.

31. Ibid; 52-53.

32. Joseph Borkin, The Crime and Punishment of I.G. Farben. The birth, growth and corruption of a giant corporation (London: André Deutsch 1979), 15861. Peter Hayes, Industry and Ideology. I.G. Farben in the Nazi Era (Cambridge: Cambridge University Press 1987), 377. Raymond G. Stokes, Opting for Oil. The Political Economy of Technological Change in the West German Chemical Industry, 1945-1961 (Cambridge: Cambridge University Press, 1994), 72-73.

33. UAR, DIR 23, 348.1, Report of the Committee appointed to review the Decartelisation Program in Germany, 27-30.

34. Ibid.; 25.

35. Maddox, The War Within World War II, 145.

36. Ibid. 
that the breaking up of the only locomotive manufacturer in Germany would be wise in a period in which transportation had been almost at a standstill. In addition, Clay also stated that he was not against vertical integration, but that he was opposed to horizontal integration. No action had to be taken against companies in the heavy industry, but only against companies that had monopolies in consumer goods. In reaction, forty-eight members of the Decartelisation Branch signed a statement to president Truman "in protest against the failure to eliminate the German cartels" and expressing their concerns about Clay's policy review.

As a concrete indication that American responsibility for the breaking up of German monopolies is being cast aside, the Decartelisation Branch which has been reduced in strength from 150 to about 50 in 18 months, is being further reduced to about 25, including clerical help. Furthermore, this skeleton force will have no field staff for direct investigation of German cartels. This new policy is based on the direct orders of Lt. Gen. Lucius Clay, AMG in Germany. It directly reverses our original stand on German cartels and provides the Germans with decisive powers regarding the future status of German monopolies and trusts. ${ }^{37}$

Soon after the elections of 1948 the re-elected president Truman appointed the Ferguson committee to survey the policy and status of the American decartelization policy in Germany. ${ }^{38}$ A year later the New York Times summarized the committee's 135 page report by stating that US occupation officials had failed to smash any of Germany's giant monopolies. ${ }^{39}$ A little further on it wrote that high decartelization officials were out of step with the presidential policy, fearing it would impede German recovery. According to the most critical committee member the deconcentration program had been "completely nullified." ${ }_{40}$ The committee had further observed that "some, including those who are responsible for the review of the actions, have not always been in complete sympathy with the program." Governor Clay was criticized on the ground that he had modified the program. ${ }^{41}$

37. Dennis Merrill (ed.) Documentary History of the Truman Presidency, Volume 3, United States Policy in Occupied Germany after World War II: Denazification, Decartelisation, Demilitarisation, and Democratization (Bethesda, MD: University Publications of America 1995), 555-58.

38. UAR, DIR 23, 348.1, Report of the Committee appointed to review the Decartelisation Program in Germany.

39. New York Times, Apr 30, 1949.

40. Ibid.

41. Ibid. 
Clay was furious about all the criticism and he threatened to resign as early as January 1949. On May 3, 1949 president Truman released a statement on Clay's retirement from the service. In fact, Clay did not want to retire at all, but had overplayed his hand. During World War II Truman's War Investigating Committee had exposed IG Farben's role for the first time. ${ }^{42}$ Roosevelt's trust busting drive was completely supported by Truman, also after his re-election. Two weeks later Truman appointed John McCloy as US High Commissioner for Germany. As a lawyer and advisers to big American firms McCloy had travelled several times to Germany before the war. Stimson had selected him as an assistant secretary of war in 1941. After the war he returned to business and became partner with Rockefeller's law firm Milbank, Tweed, Hadley \& McCloy. ${ }^{43}$ Nevertheless, after his appointment in July 1949 McCloy stated:

It is my intention to continue the enforcement of the decartelisation program with the greatest emphasis that is possible and practical, in order to establish within the Federal Republic of Germany a free and democratic economy. ${ }^{44}$

Whatever McCloy's intentions may have been, US administration was sharing Jean Monnet's opinion on recrudescence of cartels in Europe. In a conversation in Paris with a US representative Monnet had stated that:

Unless the United States took measures against the revival of German cartels, French and other European businessmen would soon be getting together with them. He discounted the possibility that British or French authorities in Germany would give much support to an anti-cartel policy. Monnet added that within six months, if nothing were done in Germany, the cartels will have reformed and the possibility of any effective action being taken will be lost. ${ }^{45}$

The efforts of the Western Allies to create one Western zone culminated in 1949 in the formation of the Federal Republic of Germany (FRG). Deconcentration policy nonetheless remained in the hands of the Military Governors of the Western zones until March 1951. The revised Occupation Statute then provided that the reserved powers

42. Maddox, The War Within World War II, 172-73.

43. Kai Bird, The Chairman: John J. McCloy: The Making of the American Establishment (New York: Simon \& Schuster, 1992) passim.

44. Maddox, The War Within World War II, 177.

45. NARA, RG 59, Lot files, Economic bureau, international business practices division, 1944-1952, Folder restrictive business practices, 1944-1949, Your Inquiry re. M. Monnet report on recrudescence of cartels, Nov 14, 1949. 
relating to deconcentration would be exercised only to ensure the completion of the current Allied programs. In 1950, however, the tide was turning. The Schumann Plan was launched in May, which was the first move towards the creation of the European Coal and Steel Community (ECSC). In fact, it solved the decartelization problem of the steel and coal industry in Germany. According to the president of the Schumann Plan High Authority, Monnet:

The Treaty, which is the first anti-trust law in Europe, gives us a mandate to disband cartels, to forbid restrictive practices and to prevent any excessive concentration of economic power. Thus, under a system of wholesome competition, the production of coal and steel will really be at the service of the consumers. ${ }^{46}$

Monnet's genuine enthusiasm for his creature nonetheless did not reflect the reality of state of the European antitrust policy at the time. The formation of the ECSC is by some authors even interpreted as some kind of a continuation of the steel cartel of the 1930s. ${ }^{47}$ In addition, the break-up of IG Farben in September 1950 was also not part of a general dismantling of West German industry. It actually marked the beginning of a fade out of the Allied decartelization program. Moreover, the early cold war became hot. In June 1950, the war broke out in Korea, leading to the largest rearmament boom since World War II. Huge worldwide government spending on armaments stimulated the world economy ${ }^{48}$ That did not mean that antitrust legislation was now completely moved into the background. In the FRG under strong influence of the Ordo Liberals and its most influential representative in government Ludwig Erhard, who favored competition above state dirigisme and planning, antitrust legislation was drafted. ${ }^{49}$ However, strong opposition of the German industry delayed the adoption of the first antitrust law in Germany until 1957. ${ }^{50}$

46. NARA, Rg.469, Office of Special Representatives in Europe, OGC, Folder restrictive business practices, 1944-1949, Apr 1951.

47. John Gillingham, A Case of Continuity: The Cartelization of the Western European Montanindustrie 1933-1945 and the European Coal and Steel Community (St. Louis: Center for International Studies, University of Missouri, St. Louis, 1979), 1. Carl Strikwerda, "The Troubled Origins of European Economic Integration: International Iron and Steel and Labor Migration in the Era of World War I,” The American Historical Review, 4 (1993): 1128.

48. Derek Howard Aldcroft, The European Economy 1914-2000 (Abingdon: Routledge 2001), 123.

49. John Owen Haley, Antitrust in Germany and Japan. The First Fifty Years, 1947-1998 (Seattle: University of Washington Press, 2001), 45-48. Freyer, Antitrust and Global Capitalism, 260-69.

50. Braun, The German Economy, 180. 
In the early 1950s it was reported that the Germans had not really discussed the draft antitrust law with the Americans, and that the latter might disagree with it because deconcentration was not included in the draft. ${ }^{51}$ The West German antitrust law prohibited cartels and other restrictive business practices, it nonetheless was not very effective to stop concentration in West German industry. On the contrary, concentration in the FRG, like in other industrialized countries, actually increased during the 1950s and 1960s, particularly in shipbuilding, mining and the electrical, chemical, and automobile industries. ${ }^{52}$ Cartels were made illegal in the FRG, however, large oligopolies were not.

Volker Berghahn describes how the Ruhr industrialist put pressure on the West German government to legalize cartels again during the 1950s. ${ }^{53}$ Cartels, however, remained banned. According to Berghahn the acceptance by West German industrialist of the American decartelization plans formed the cornerstone of the Americanization of their economy. ${ }^{54}$ Decartelization, however, was only one part of the antitrust policy the Americans had in mind for Germany after the war; deconcentration was the other side of the coin. Nevertheless, except for a few cases which have been described above, complete dismantling or deconcentration in West Germany had faded out during the 1950s. German industry's resistance towards American antitrust policy, not uncommon supported by their sympathizers in American business circles, did not result in a restoration of prewar German business conditions. The question is whether that would have served the interest of the West German industry anyway. More importantly, however, the soup was not as bad as it was served.

\section{Role of Cartels and Oligopolistic Practices in Italy}

Around the First World War the level of cartelization of the Italian economy cannot be compared to the one characterizing prewar Germany. Domestic cartels existed, but to a lower extent. During the interwar period Italian participation to international cartels was an exception more than a rule. ${ }^{55}$ Conventional wisdom about the concentration level of the Italian industrial economy affirms that it was

51. AkzoNobel Historical Archive (ANHA), 551, Participations 1951, Report of vice chairman of the Dutch Committee of Industrial Interests in Germany on his trip to Cologne, Frankfurt, and Bonn, 4-12 Jul 1951.

52. Braun, German Economy, 180.

53. Volker R. Berghahn, The Americanisation of West German Industry (Berg: Leamington Spa/ New York 1986), 124-32.

54. Ibid., 331; Schröter, Americanization, 68.

55. Virgilio D’Agnino, I cartelli industriali nazionali e internazionali (Turin: Fratelli Bocca, 1928). 
so high that cartels were to some extent superfluous. A recent study, however, challenges the impression of the contemporary actors, pointing out that the level of concentration of Italian industrial sectors was low compared to other European countries, although it could not be considered a competitive economy, with the exception of a very limited number of sectors (mainly the textile and the paper and publishing ones). Nevertheless the same study underlines that between 1913 and 1952 (and in some case also later, until 1971) concentration level was substantially increasing. ${ }^{56}$

Immediately after the Second World War, the Ministry for the Costituente (responsible for the preparation of the procedures for the new constitution) made an in-depth analysis of the industrial, financial, and commercial structure of the country. ${ }^{57} \mathrm{~A}$ special commission prepared a report that has been for many years a sort of consensual description of the Italian economy at the time..$^{58}$ The long tradition of trade tariffs and protectionism, together with-and amplified by-the dominant mentality and practices of the previous fascist regime, paved the way to a monopolistic and/or oligopolistic situation in almost all the industrial sectors. Moreover, during the 1930s the fascist government, as many other governments in Europe, pushed companies to set up cartels-the Italian word used was consortia-as an instrument to reinforce the weak structures of firms but also offering a strong support to the big industrial and financial groups which were called to play a leading role in this process. According to literature before the war there were 144 national and 111 local cartels or consortia in several branches of manufacturing in Italy, an important number for this country but in any case less than 5 percent of the number of cartels established in Germany in the same period. ${ }^{59}$ Looking at the concentration of Italian industry, the census of 1940 showed that more than 22 percent of all Italian employees and 38 percent of all horse power installed in Italy

56. L. Bargigli and M. Vasta, "Ownership and Control in the Italian capitalism," in R. Giannetti and M. Vasta eds., Evolution of the Italian Enterprise in the $20^{\text {th }}$ Century (New York: Physica, 2006), 111-52.

57. Federico Caffè, "Un riesame dell'opera svolta dalla Commissione economica per la Costituente," in Studi per il ventesimo anno dell'Assemblea costituente, vol. III (Florence: Vallecchi, 1969), 35 ff.

58. Ministero per la Costituente, Rapporto della Commissione economica (Rome: Istituto Poligrafico dello Stato 12 voll., 1947).

59. Gualberto Gualerni, Storia dell'Italia industriale. Dall'Unità alla Seconda Repubblica (Milan: Etas Libri, 1994), 118-22; Giovanni Federico and Renato Giannetti, "Italy: Stelling and Surpassing," in James Foreman-Peck and Giovanni Federico eds., European Industrial Policy: the Twentieth Century (Oxford: Oxford University Press, 1999), 133-34; Luciano Segreto, "Industrial Capitalism and Political Constraints: the Bureaucratization of Italian Economy during the fascist Regime" in Christopher Kobrak and Per Hansen eds., European Business, Dictatoriship, and Political Risk (Oxford: Berghahn Books, 2004), 225-30. 
were concentrated in 816 plants with more than 500 employees, that is, 0,37 percent of the total. Between 60 and 70 percent of industrial assets belonged to stock companies, and less than hundred among them, 0,21 percent of the total, owned two-third of the total.

Ownership concentration was even more impressive: 462.123 persons were owners of shares; out of them 851, that is, 0,18 percent, owned 54 percent of the total amount of those shares. The role of the State in the ownership structure, via many holdings (IRI, AGIP, Finsider, STET, Fincantieri, etc.) was very important as well, because according to an evaluation of that time, 15 percent of industrial assets of the country were controlled by the State. ${ }^{60}$ The level of industrial production concentration, according to table 1, was extremely high in a large number of decisive sectors. Both private- and state-owned companies contributed to this situation.

Although the relatively low level of scientific accuracy of this data (which has been in any case confirmed by the more recent literature about the role of networks and business groups in the Italian economy of that time $)^{61}$, their political relevance was nonetheless extremely high because they were commonly used both in the public as well in the private discourses about the concentration level of the Italian economy, and they were available to the main actors of the discussion about the US antitrust policy in Italy, the Italian and the US administration, as well as the Italian business community. In the first months after the war, the Italian government indicated its desire to cooperate with the United States and other countries "in freeing international trade from artificial restrictions." ${ }^{62}$ The US administration took this

Table 1 Level of industrial production concentration

\begin{tabular}{llll}
\hline & No. of groups & Production (\%) & $\begin{array}{l}\text { Of which by state-owned } \\
\text { companies (\%) }\end{array}$ \\
\hline Electricity & 8 & 77 & 29 \\
Gas & 5 & 74 & 27 \\
Car industry & 2 & 68 & 7 \\
Iron and steel & 6 & 86 & 57 \\
Cement & 6 & 57 & 5 \\
Rubber & 4 & 82 & - \\
Synthetic ammonia & 2 & 86 & - \\
Artificial textile & 2 & 90 & - \\
Typewriting machines & 4 & 75 & - \\
Soda & 1 & 100 & - \\
\hline
\end{tabular}

Source: Ministero per la Costituente, Rapporto della Commissione Economica, II, Industria,

I. Relazione, vol. 2, Rome, Istituto Poligrafico di Stato, 1947, 216-17.

60. Ministero per la Costituente, Rapporto della Commissione economica, vol. II, Industria, I, Relazione, vol. 2, 201-25.

61. L. Bargigli and M. Vasta, "Ownership and Control in the Italian capitalism," 149 .

62. RG 59, Dec file 1945-49, DF 865.602, cartels in Italy 1945-63, State Department to US Mission in Rome, Feb 14, 1947. 
official declaration very seriously, but it would discover in the following years how distant these propositions were from the concrete attitude of the Italian side to fight cartels and other restrictive business practices that were dominating the economy of the Peninsula. In 1947, during the complex procedures dealing with the signature of a new commercial treaty between Italy and the United States, the State Department produced a report on "The effects of Cartels on the Italian Economy." According to the Americans "substantial portions of Italian industry and trade were subject to restrictions imposed by cartel agreements.” These were also responsible for the unnatural distortion of the "development of Italian resources by protecting uneconomic Italian producers in some cases, and preventing expansion of Italian production and trade in accord with natural advantages in other cases."63 During the following months representative of both governments worked on a text to be included in the proposed Treaty of Friendship, Commerce and Navigation, which should specify measures to be taken in order to "prevent business practices affecting international trade which restrains competition, and which are engaged in or made effective by combination, agreement or other arrangement among public or private commercial enterprises." 64

But after several discussions, also within the US administration, the decision taken was much more pragmatic: it was "administratively impracticable, if not impossible, to squash cartels with respect to trade between two countries without at the same time following an anti-cartel policy generally." And the final observation that "the treaty is already so long, comprehensive and replete with troublesome issues that further complications, by way of additional issues, are not to be welcomed," provisionally closed the debate. ${ }^{65}$ In fact, the final version of the treaty, approved in February 1948, affirmed that the Italian government was:

to adopt all measures it consider useful and to cooperate with other participating countries with the aim of avoiding the use by private or public commercial firms of methods or business combinations that could influence the international trade by diminishing competition, limiting the access to the market or to favor monopolistic controls, whereas those methods or agreements have the effect to avoid the achievement of the common program of European recovery. ${ }^{66}$

63. Ibid.

64. Ibid; Draft of the Treaty of Friendship, Commerce and Navigation.

65. NARA, RG 59, Dec File 1945-49, DF 865.602/11-546, Coppock to Wilcox,

Oct 3, 1947.

66. Camera dei Deputati (Chamber of the Deputies), Law proposal n. 36, meeting of the 30th of June 1948, Ratification of the agreement for the economic cooperation between Italy and the United States of America signed on the 26th of June 1948. 
As suggested in a seminal article by Richard Griffiths and Wendy Asbeek Brusse, the Marshall Plan offered the framework in which the US anticartel initiative could be really transformed into an effective and more comprehensive policy. ${ }^{67}$ According to Economic Cooperation Administration (ECA) director, Paul Hoffman:

restrictive business practices worried ECA, because we are convinced that their diffusion in Europe represents one of the major obstacles for the diminution of unit costs, the productivity and revenues growth, and to a more efficient competitiveness of Western Europe in international trade. Thereafter they represent some impediments to achieving the goals of ECA. ${ }^{68}$

The adaptation of this policy in Italy nonetheless took many forms, partly because of the obsolete structure of the industrial apparatus, and of the legal and cultural structure of the economic framework, and partly because of the strong prolonged rejection of the business community and the political elites that supported the centrist government. In fact, the aim was not easy to be reached at all. The goals of ECA in Western Europe, and not just in Italy, could only be achieved through a sort of revolution of the economic culture still dominant on the continent. Only when this first-and difficult task-would be reached, it could have been possible for these new ideas to penetrate the political, legislative and administrative apparatus. Finally, it would have been also thinkable to work for the introduction of a liberal reform in the economic institutions, in line with competitive instead of restrictive business practices. ${ }^{69}$

The US representatives in Europe were often between the devil and the deep sea. In some moments their vision was quite pragmatic, by considering that "the differences between the institutions and the way of thinking are so big that it would be hazardous for the US soliciting a specific reform program" to their European counterparts. In other moments they appeared quite aggressive, suggesting that the ECA missions should make the point about the use of ECA dollars or the counterpart funds by firms that were adopting restrictive business practices, even to the point of including antirestrictive clauses in loan contracts and other deals ${ }^{70}$.

67. Wendy Asbeek Brusse and Richard T. Griffiths, "L'European Recovery Program e i cartelli," in Studi storici, 36 (1996), n. 1, 41-68.

68. NARA, RG 469, Records of US foreign assistance, Office of Special Representative in Europe (OSR), OGC, Subject files, 1948-1953, Folder Restrictive business practices, Instructions A-252, May 6, 1950.

69. Ibid; An ECA program for dealing with restrictive business practices, Sep 20, 1949.

70. Ibid; RG 469, OSR/E, OGC, Subject files 1948-1953, Folder restrictive business practices, Instructions, May, 6, 1950; Lack of activity on restrictive practices and price fixing, Jul 17, 1950. 
A clear suggestion to the staff of US mission in Rome (as well as in many other Western European countries) was to work with national governments to change the legislation. This, however, was a delicate matter, because in those activities it was necessary to avoid any "doctrinarian attitudes, the inclination to exaggerate with the generalized sermons about the merits of competition, as well as any attempt of the United States to impose its economic and legal model on the participant countries." 71

The United States encouraged the introduction of legal norms to enhance competition, using all possible ways to influence the Italian political elites and the ruling classes, which were officially in favor of the campaign against restrictive business practices. The US representatives in Rome pressed to the point of redacting many drafts of the laws to eliminate restrictive business practices, and particularly cartels, and to introduce economic liberalization. Nevertheless, they avoided to use any form of pressure linking the continuation of the Marshall Plan in Italy to the adoption of liberalization procedures. The strategic aim to contain communism acted as a sort of invisible barrier stopping the most radical critics against the Italian government. $^{72}$

As a result, US representatives could only record several times, between 1949 and 1953, and even later, in 1960, that the Italian government was going to present to the Parliament the law to eliminate restrictive business practices, but during those years discussion about the draft law never reached the assembly, slowly navigating in several commissions of the Chamber of Deputies or the Senate. ${ }^{73}$ Even the 1951 Benton amendment, engaging United States to push the development of competitive economies in Western Europe, despite linking the continuation of economic aid to concrete policies to discourage cartels and monopolistic commercial practices, was never effective. ${ }^{74}$

The attempt to enroll the noncommunist trade unions in the battle against cartels was never successful in Italy, and the Italian Parliament postponed for year the discussion of the draft law for an antitrust legislation, finally prepared by the government after the first drafts channeled by the US mission in Rome. Much more rapid and efficient the Parliament was in 1952-1953, when the government assigned to

71. Ibid; RG 469, OSR/E, OGC, Subject files 1948-1953, Folder restrictive business practices, Instructions, May 6, 1950.

72. Ibid., RG 469, Deputy Director for operations, Office of European Operations, Italy Division, 1948-1954, Folder Governmental regulations, cartels.

73. NA, RG 59, 865-054, 1950-1954, Department of State o American embassy in Rome, Jun 2, 1952; ibid; 1960-1963, Department of State to US Embassy in Rome, Mar 8, 1960.

74. Asbeek and Griffiths, "L'European Recovery Program e i cartelli,” 49-50. 
a new public owned company, ENI (Ente Nazionale Idrocarburi), the monopoly of oil and gas drillings in Italy, despite the efforts by the American oil companies and the US representatives in Rome to leave the door also open to private investments in this sector. ${ }^{75}$

In fact, the dominating economic culture of the government, especially in the majority party, the Christian Democratic Party, was in favor of a State interventionist policy. The idea was that the historical, social and economic weaknesses of the country could only find a solution through a strong investment policy of the State holding company, IRI, and the very large industrial apparatus it controlled. The private sector, after reaching a sort of division of labor with the stateowned companies, profited from this this economic culture, which implied the absence of competition. ${ }^{76}$

Many years later, in 1970s, the President of the Confederation of Italian Industrialist and former Governor of the Bank of Italy, Guido Carli, stated:

Italian entrepreneurs did never seriously fight for a law to protect the competition. In the end they did their best in those years to stop it. But all the Italian political, cultural and ideological world under evaluate the theme of free competition and of its effective functioning: the big political parties, the Christian democratic party, the Communist party, the Socialist party were against the ideology of competitiveness and thereafter of the efficiency (...). Italian entrepreneurs have a heavy responsibility, because they never wanted to be deeply involved in an open battle in favour of competition (...) They forgot that Italy was the most relevant example of a mixed economy with two sectors, the public one and the private one. A legislation for the free competition would have been the only efficient defence against the field's invasion of the state owned industries (...) and maybe also an instrument to avoid its degeneration. The lack of perception of this issue (...) has been one of the capital mistake made by the Italian ruling classes. ${ }^{77}$

These words were not so different from those used in 1952 by a member of the US mission in Rome, when he wrote that while the Italian

75. Luciano Segreto, "Gli investimenti americani in Italia (1945-1963)," in Studi Storici, 36 (1996), 299-309.

76. Fabrizio Barca, "Compromesso senza riforme nel capitalismo italiano," in Fabrizio Barca ed., Storia del capitalismo italiano (Rome: Donzelli, 1987), 73-89; Gloria Pirzio Ammassari, La politica della Confindustria (Naples: Liguori, 1976), 30-31; Liborio Mattina, Gli industriali e la democrazia (Bologna: il Mulino, 1991).

77. Guido Carli, Intervista sul capitalismo italiano, ed. E. Scalfari (Bari: Laterza, 1977), 21-23. 
Government has moved a long way toward liberal trade policies against mounting domestic opposition and has introduced a cartel registration bill into the Parliament (...) business men in Italy too often have restrictive, complacent and static attitudes. They pay too little attention to improving production, seeking new markets, cutting cost. ${ }^{78}$

After almost six years of unsuccessful attempts to introduce an antitrust law, the US representative in Rome admitted that "the problem of eliminating restrictive business practices in Italy raises issues which strike closely at the country's prevailing economic philosophy and its institutional framework." This general evaluation permitted also for the first time to go deeper into the strictly cost-benefits analysis. The report stated that "Italian industrial and distribution circles as a whole prefer under present conditions to make their profits from high margins and relatively constant sales rather than undertake a dynamic increase in output with low units marks-ups," concluding that this approach reflected "substantially the prevalent state of mind of the industrialists, not only in Italy, but in other Western European countries." 79 A few weeks later the US mission in Rome recognized that "such practices (...) constitute one of the important obstacles to the attainment of broad United States objectives here," and that the progress of any further action taken by the US mission in Rome would be "gradual." 80

During the 1950s a small section of the public opinion, and an even more minuscule part of the political elites and the parties represented in the national Parliament, conducted a campaign for the adoption of antitrust legislation in Italy. Conferences and several initiatives characterized their attempt, but the absence of a real unity among the political and cultural opposition to cartels and monopolies did not lead to a concrete success. Nevertheless, the increasing influence of this groups in the political arena, as well as the new political atmosphere with the birth of the first centre-left governments in the early 1960s, obtained a result. After the presentation to the Italian Chamber of Deputies of nine law projects against monopolies and trusts, and or to protect and favor competition the Italian parliament was involved in a larger discussion. Between 1961 and 1965 a Parliamentary Commission examined the Italian economic structure,

78. NARA, RG 59, lot file n. 58, D 375, Subject Files relating to Italian Affairs, 1944, 1956, box 13, Benton and Moody Amendment and productivity.

79. NARA, RG 59, 800.054/2-7952, Report of restrictive business practices in Italy, Jun 30, 1952.

80. NARA, RG 469, Director for operations, Office of European Operations, Italy Division 1948-1958, Folder Governmental regulation, cartels, US mission in Rome to State Department, Aug 25, 1952. 
the level of competition, and the role of cartels and monopolies. The US Embassy in Rome reported regularly on the evolution of the investigation and was requested by Italians of offer substantial assistance, however, it was rather pessimistic about the outcome of the committee and the possibilities of an enactment of Italian antitrust law. ${ }^{81}$ The final results of that investigation confirmed the US views that due to the difficulties to evaluate the data, and market conditions it was not permitted to conclude that Italian economy was under the control of trusts, oligopolies, and monopolies. This was just another confirmation of the power held by the guardians of the anticompetitive structures of Italian capitalism. ${ }^{82}$

\section{Conclusion}

The US administration envisioned a unified free European market without cartels as early as 1943, however, it would take another 50 years before its ideas would be implemented. Why the United States was not able to implement its policies directly after war in Italy and West Germany? Both Italy and Germany had been in favor of cartels and restrictive business practices, but after the war these two former Axis powers were defeated powers, which were either occupied or controlled by the Western Allies, of which the United States had the most ambitious views regarding antitrust policy, and apparently the power to implement these. Both defeated nations were strongly dependent on postwar American aid.

The Americans nonetheless were not successful with the implementation of their views regarding antitrust policy in the immediate postwar period for various reasons. European integration, beginning with the establishment of the European Community for Coal and Steel, solved many dilemmas concerning restrictive business practices raised during the discussion from 1943 to 1951, permitting in some cases cartels for coal and steel, natural resources, and strategic materials. In the meanwhile, the priorities had changed, recovery and political stabilization in Europe had become more important to the Americans. The Cold War postponed the implementation of American ideas about postwar Europe. Besides, the American antitrust program-not always crystal clear and sometimes even contradictory-and the economic postwar reality in Europe were two separate worlds.

81. NARA, RG 59, 865.054/5-861, Rome Embassy to State Department, May 8, 1961. 865.054/3-1662, Rome Embassy to State Department, Mar 16, 1962.

82. Mattia Granata, Cultura del mercato. La Commissione parlamentare d'inchiesta sulla concorrenza (1961-1965) (Soveria Mannelli: Rubettino, 2007). 
However, despite the similarities there were big differences between the German and Italian cases. In Germany antitrust legislation was drafted mainly by German Ordo Liberals which was adopted in 1957, however, in a much softer fashion than the Americans had envisioned originally. The new antitrust law prohibited cartels and other restrictive business practices, but did not stop further concentration in West German industry. In Italy antitrust legislation was drafted by the Americans, but never discussed in parliament. Italian antitrust law, following the special committee of the European Union of the 1980s, was adopted, and an agency was only set up, in 1990. Eventually, the Germans thus much better adapted, after initial resistance of German big business, to the American plans than the Italians, however, only in an amended form. The Italian resistance-but we used even the expression "prolonged rejection"- to economic reforms were much stronger. The creation of ENI and the introduction of a monopoly for oil and gas research and exploitation on the national territory could be considered the best example of the Italian attitude, especially if one considers the American position, and the impressive pressure made by the US oil companies, both on the US and Italian government to avoid that solution. The 1963 Italian parliamentary committee on competition concluded in its 12 volume report that in Italy there was no clear evidence of monopolies and cartels, although a minority report drew the reverse conclusion. In the next 25 years nobody in Italy ever mentioned the word cartel or restrictive business practice anymore.

This article has challenged the conventional wisdom that, during the 1950s, European governments were more conscious about the negative effects of the cartels in their economies, also thanks to the pressures of US administration and the influence of American probusiness and proliberalization culture. In fact, most of the European antitrust and anticartel legislation was not a consequence of US pressures, but a way to evade concrete action against all actors responsible for restrictive business practices. In Europe, governments even when they got the effective power to intervene, used this possibility only with the most delicate circumspection, and only when the existence of a cartel had been disclosed. In the end, the American crusade against cartels and restrictive business practices was not a success, and it ran aground amid obstructionism and misunderstandings.

From the business culture point of view the article confirms that Americanization is a too wide concept for a comprehensive interpretation of the transformation that occurred among the European firms in the decades after the end of World War II. The image of an hybridization, suggested in the literature, to discuss the process involving European economy and European firms, seems to be reinforced as well as the other image suggesting that European governments and 
business community selected only those factors of the US economic and corporate model that were useful, and that could be implemented in Europe without a deep-and most probably too expensive in social and political terms-change of cultures and behaviours. ${ }^{83}$

It is impressive to read today the final lines of the report written in January 1943, and quoted in the first pages of this article. Their capacity of forecasts has probably gone well beyond the author's imagination and intelligence. He was suggesting that only with a European supranational institution it could have been less difficult—but in any case not sureto introduce and to make successful an anticartel policy in Europe. But even in case of a success in this field, he was also aware that:

if the powers of the European economic authority regarding industrial combinations were limited to negotiations with the governments of individual nations in respect of policy, it could promulgate international standards for adoption by several national legislations or by international convention. It is extremely doubtful, however, that this alternative would prove effective either with regard to the suppression or the control of monopolistic combinations. ${ }^{84}$

When the war was still to be decided, this document was offering a vision of the future of Europe that became a reality only many years later. Unfortunately, these forecasts were extremely precise, and not only regarding the antitrust policy and the fight against cartels.

\section{Bibliography of Works Cited}

\section{Books}

D’Agnino, Virgilio. I Cartelli Industriali Nazionali e Internazionali. Turin, Italy: Fratelli Bocca, 1928.

Aldcroft, Derek Howard. The European Economy 1914-2000. Abingdon, UK: Routledge, 2001.

83. L. Segreto, “Americanizzare o modernizzare l'economia? Progetti americani e risposte italiane negli anni Cinquanta e Sessanta,” in Passato e Presente, n. 37, Jan-Apr 1996, 57; Jonathan Zeitlin, "Introduction: Americanization and its Limits: Reworking US Technology and Management in Post-War Europe and Japan," in Jonathan Zeitlin and Garry Herrigel Eds., Americanization and its Limits, 34-41; Franco Amatori and Andrea Colli, Business History. Complexities and Comparisons (London: Routledge, 2011), 183-94; Harm G. Schröter, "The European Enterprise, Its relevance and Problems," in Harm G. Schröter, The European Enterprise. Historical Investigation into a Future Species (Berlin: Springer), 3-22.

84. NARA, RG 59, Lot files, Economic bureau, international business practices division, 1944-1952, Folder restrictive business practices, 1944-49, "Cartels and other forms of private monopoly in European economic reconstruction," Jan 15, 1943, cit., 21. 
Amatori Franco, and Colli Andrea. Business History. Complexities and Comparisons. London, UK: Routledge, 2011.

Barjot, Dominique, ed. Catching-up with America: Productivity Missions and the Diffusion of American Economic and Technological Influence After the Second World War. Paris, Italy: Press de Université de Paris Sorbonne, 2002.

Berge, Wendell. Cartels, Challenge to a Free World. Washington, DC: Public Affairs Press, 1944.

Berghahn, Volker R. The Americanisation of West German Industry. Leamington Spa, UK: Berg, 1986.

Bird, Kai. The Chairman: John J. McCloy: The Making of the American Establishment. New York: Simon \& Schuster, 1992.

Borkin Joseph, and Charles A. Welsh. Germany's Master Plan. The Story of Industrial Offensive. New York: Duell, Sloan and Pearce, 1943.

Borkin, Joseph. The Crime and Punishment of I.G.Farben. The Birth, Growth and Corruption of a Giant Corporation. London, UK: André Deutsch, 1979.

Braun, Hans-Joachim. The German Economy in the Twentieth Century. The German Reich and the Federal Republic. London, UK: Routledge, 2011.

Carli, Guido. Intervista sul capitalismo italiano, ed. E. Scalfari. Bari, Italy: Laterza, 1977.

Djelic, Marie-Laure. Exporting the American Model. The Post-war Transformation of European Business. New York: Oxford University Press, 1998.

Fligstein, Neil. The Transformation of Corporate Control. Cambridge, MA: Harvard University Press, 1990.

Freyer, Tony A. Antitrust and Global Capitalism, 1930-2004. Cambridge: Cambridge University Press, 2006.

Gillingham, John. A Case of Continuity: The Cartelization of the Western European Montanindustrie 1933-1945 and the European Coal and Steel Community. St. Louis: Center for International Studies, University of Missouri, 1979.

Granata, Mattia. Cultura del mercato. La Commissione parlamentare d'inchiesta sulla concorrenza (1961-1965), Soveria Mannelli, Italy: Rubettino, 2007.

Gualerni, Gualberto. Storia dell'Italia industriale. Dall'Unità alla Seconda Repubblica. Milan, Italy: Etas Libri, 1994.

Hayes, Peter. Industry and Ideology. I.G. Farben in the Nazi Era. Cambridge: Cambridge University Press, 1987.

Haley, John Owen. Antitrust in Germany and Japan. The First Fifty Years, 1947-1998. Seattle: University of Washington Press, 2001.

Jones, Geoffrey. Multinationals and Global Capitalism from the Nineteenth to the Twenty-first Century. Oxford: Oxford University Press, 2005.

Kipping, Matthias, and Ove Bjarnar, eds. The Americanisation of European business: the Marshall Plan and the transfer of US management models. London, UK: Routledge, 1998. 
Kipping, Matthias, and Nick Tiratsoo, eds. Americanisation in the Twentieth Century Europe: Business, Culture, Politics, vol. 2. Lille, Italy: Centre d'Histoire de l’Europe du Nord-Ouest Université Charles-de-Gaulle Lille 3, 2002.

Koistinen, Paul A. C. Arsenal of World War II: the politcal economy of American warfare, 1940-1945. Lawrence: University Press of Kansas, 2004.

Kunz, Diana B. Butter and Guns. America's Cold War Economic Diplomacy. New York: Free Press, 1997.

Maddox, Robert Franklin. The War Within World War II. The United States and International Cartels. Westport, CT: Praeger, 2001.

Mattina, Liborio. Gli industriali e la democrazia. Bologna, Italy: il Mulino, 1991.

Merrill, Dennis, ed. Documentary History of the Truman Presidency, Volume 3, United States Policy in Occupied Germany after World War II: Denazification, Decartelisation, Demilitarisation, and Democratization, University Publications of America, 1995.

Ministero per la Costituente. Rapporto della Commissione economica, vol. 12. Rome, Italy: Istituto Poligrafico dello Stato, 1947.

Pirzio Ammassari, Gloria. La politica della Confindustria. Naples, Italy: Liguori, 1976.

Schröter, Harm G. Americanisation of the European Economy. A Compact Survey of American Economic Influence in Europe Since the 1880s. Dordrecht, the Netherlands: Springer, 2005.

Stokes, Raymond G. Opting for Oil. The Political Economy of Technological Change in the West German Chemical Industry, 1945-1961. Cambridge: Cambridge University Press, 1994.

Wells, Wyatt. Antitrust \& the Formation of the Postwar World. New York: Columbia University Press, 2002.

Wiesen, S. Jonathan. West German Industry and the Challenge of the Nazi Past, 1945-1955., Chapel Hill: University of North Carolina Press, 2001.

Zeitlin, Jonathan, and Gary Herrigel, eds. Americanization and Its Limits. Reworking US Technology and Management in Post-War Europe and Japan. Oxford: OUP, 2000.

\section{Articles and Essays}

Asbeek Brusse, Wendy, and Richard T. Griffiths. "L'European Recovery Program e i cartelli.” Studi Storici, 36 (1996): 41-68.

Barca, Fabrizio. "Compromesso senza riforme nel capitalismo italiano." In Storia del Capitalismo Italiano, edited by Fabrizio Barca, 3-78. Rome, Italy: Donzelli, 1987.

Bargigli, Leonardo, and Michelangelo Vasta. "Ownership and Control in the Italian Capitalism." In Evolution of the Italian Enterprise in the $20^{\text {th }}$ Century, edited by R. Giannetti and M. Vasta, 111-152. New York: Physica, 2006.

Caffè, Federico. "Un riesame dell'opera svolta dalla Commissione economica per la Costituente." In Studi per il ventesimo anno dell'Assemblea costituente, vol. 3. Florence, 33-45. Italy: Vallecchi, 1969.

Djelic, Marie-Laure. "Does Europe Mean Americanization? The Case of Competition." Competition \& Change 6 no. 3 (2002): 233-50. 
Dumenile, Gérard Mark Glick, and Dominique Levy. "History of Competition Policy as Economic History.” Antitrust Bulletin 42 (1997): 373-417.

Federico Giovanni, and Giannetti Renato. "Italy: Stelling and Surpassing." In European Industrial Policy: The Twentieth Century, edited by James ForemanPeck and Giovanni Federico, 124-151. Oxford: Oxford University Press, 1999.

Maier, Charles. "Politics of Productivity: Foundations of American Economic Politics after World War II." International Organisation 31 (1977): 707-33.

McClade, Jacqueline. "Lo zio Sam ingegnere Industriale. Il Programma Americano per la Produttività e la Ripresa Economica dell'Europa Occidentale 1948-1958." Studi Storici 36 (January-March 1996): 9-40.

Mori, Giorgio. "L'economia italiana tra la fine della seconda Guerra mondiale e il 'secondo miracolo economico', (1945-58)." In Storia dell'Italia repubblicana, volume primo, la costruzione della democrazia. Dalla caduta del fascismo agli anni cinquanta, 169-73. Turin, Italy: Einaudi, 1994.

Rossi, Nicola, and Gianni Toniolo. "Italy." In Economic Growth in Europe since 1945, edited by Nicholas Crafts and Gianni Toniolo, 439-41. Cambridge: CUP, 1996.

Schröter, Harm G. "The European Enterprise, Its relevance and Problems." In The European Enterprise. Historical Investigation into a Future Species, edited by Harm G. Schröter, 3-22. Berlin-Heidelberg, Gemany: Springer.

Segreto, Luciano. "Americanizzare o modernizzare l'economia? Progetti americani e risposte italiane negli anni Cinquanta e Sessanta." Passato e Presente 37 (January-April 1996) 55-83.

Segreto, Luciano. "Gli investimenti americani in Italia (1945-1963)." Studi Storici 36 (1996): 273-316.

Segreto, Luciano. "The Importance of the Foreign Constraint: Debates about a new Social and Economic Order in Italy, 1945-1955." In The Postwar Challenge. Cultural, Social, and Political Change in Western Europe, 194558, edited by Dominik Geppert, 129-35. Oxford: OUP, 2003.

Segreto, Luciano. "Industrial Capitalism and Political Constraints: the Bureaucratization of Italian Economy during the fascist Regime.” In European Business, Dictatoriship, and Political Risk, edited by Christopher Kobrak and Per Hansen, 225-30. Oxford: Berghahn Books, 2004.

Strikwerda, Carl. "The Troubled Origins of European Economic Integration: International Iron and Steel and Labor Migration in the Era of World War I." The American Historical Review 4 (1993): 1106-29.

Zeitlin, Jonathan. "Introduction: Americanization and its Limits: Reworking US Technology and Management in Post-War Europe and Japan." In Americanization and its Limits, edited by Jonathan Zeitlin and Garry Herrigel, 1-50. Oxford: OUP, 2000.

\section{Online Source}

Roosevelt, Franklin D. "Message to Congress on Curbing Monopolies.” April 29, 1938. Online by Gerhard Peters and John T. Woolley, The American Presidency Project. http://www.presidency.ucsb.edu/ws/?pid=15637 


\section{Dissertation}

Schottenstein, Alan Jay "An Analysis of the Wheeler-Lea Act and Its Administrative Agency.” MBA thesis, The Federal Trade Commission, The Ohio State University, 1951. 